\title{
Akuntabilitas Pelayanan Publik: Studi Kasus Pelayanan Perizinan Mendirikan Bangunan di Kota Makassar
}

\author{
BAHARUDDIN \\ Fakultas IImu Sosial dan IImu Politik Universitas Hasanuddin \\ email: baharuddin_fisipuh@yahoo.co.id
}

\begin{abstract}
Licensing building services in Makassar often received attention from various parties. Based on this view, this study aims to describe and analyze the accountability of the legality, profesional, authority, control, and service quality dimensions of licening services. This research applies qualitative approach and includes case study to obtain valid information. The determined informants is done through purposive sampling with the hope that informants could comprehend the substance of the problems studied. This study will reveal the public service performance as one of indicators of good governance (good governance). The results showed the legality of the licensing service is uneffective, and another point is that standard operating procedures (SOP) has not run optimally, making it less effective and efficient in completing the work.
\end{abstract}

Key Words: accountability, service performance, IMB

\begin{abstract}
Abstrak. Pelayanan perizinan mendirikan bangunan di Kota Makassar sering mendapat sorotan dari berbagai pihak. Berdasarkan pandangan tersebut kajian ini bertujuan mendeskripsikan dan menganalisis akuntabilitas dari aspek legalitas, profesional, kewenangan, pengawasan, dan dimensi kualitas pelayanan perizinan. Kajian ini menggunakan pendekatan kualitatif dan termasuk jenis penelitian studi kasus Untuk mendapatkan informasi yang valid maka penentuan informan dilakukan secara purposive sampling dengan harapan informan tersebut memahami substansi permasalahan yang diteliti. Penelitian ini akan mengungkap kinerja pelayanan publik sebagai salah satu indikator tata kelola pemerintahan yang baik (good governance). Hasil penelitian menunjukkan legalitas pelayanan perizinan belum maksimal. Selain itu, Standar Operasional Prosedur (SOP) belum berjalan secara maksimal, sehingga kurang efektif dan efisien dalam menyelesaikan pekerjaan.
\end{abstract}

Kata Kunci: akuntabilitas, kinerja pelayanan IMB

\section{Latar Belakang}

Penyelenggaraan tata kelola pemerintahan yang baik (good governance) terletak pada seberapa jauh kolaborasi dan sinergitas antara tiga pilar bernegara, yaitu rakyat, pemerintah, dan pengusaha secara kohesif, selaras, dan seimbang (Thoha, 1998;22). Untuk itu, akuntabilitas birokrasi publik akan menjadi titik krusial bagi arah perkembangan demokrasi di Indonesia dalam waktu sekarang ini (Kumorotomo, 1999;56). Akuntabilitas (accountability) merupakan ukuran yang menunjukkan apakah aktivitas birokrasi publik atau pelayanan yang dilakukan oleh pemerintah sudah sesuai dengan norma dan nilai-nilai yang dianut oleh rakyat dan apakah pelayanan publik tersebut mampu mengakomodasi kebutuhan rakyat yang sesungguhnya.

Sistem akuntabilitas bagi lembaga pemerintah atau birokrasi publik yang memadai merupakan prasyarat penting bagi peningkatan kualitas pelayanan publik. Tanggung jawab (accountability), kepekaan pejabat dalam memahami dan menanggapi kebutuhan publik dan mudah mendapatkan informasi antara yang memerintah dan yang diperintah merupakan kriteria yang paling

Received: 23 Februari 2015, Revision: 15 Juni 2015, Accepted: 28 Desember 2015

Print ISSN: 0215-8175; Online ISSN: 2303-2499. Copyright@2015. Published by Pusat Penerbitan Universitas (P2U) LPPM Unisba Terakreditasi SK Kemendikbud, No.040/P/2014, berlaku 18-02-2014 s.d 18-02-2019 
tepat untuk mengukur administrasi publik yang demokratis. Pemerintah harus mampu memperluas alternatif penyedia pelayanan publik serta menunjang informasi atau menetapkan standar yang dapat menjamin adanya akuntabilitas yang baik di dalam pelayanan publik. Kemudian juga terdapat konsep self accountability yang pada dasarnya merupakan proses akuntabilitas internal yang sangat bergantung kepada penghayatan mengenai nilai-nilai moral atau etika para pejabat birokrat yang melaksanakan tugas pelayanan publik.

Sikap dan perilaku birokrasi yang tidak responsif, struktur, dan prosedur yang tidak adaftif dan masih prosedural, memperburuk kepercayaan masyarakat terhadap birokrasi dan menimbulkan resistensi masyarakat terhadap kebijakan publik. Oleh karena itu, maka dibutuhkan suatu tanggung jawab (accountability) terhadap pelayanan publik yang mampu merespons kebutuhan dan aspirasi masyarakat.

Dalam UU 32 Tahun 2004 tentang Pemerintahan Daerah akan semakin banyak aktivitas pelayanan yang harus ditangani Daerah. Hal ini ditambah dengan semakin kuatnya tuntutan demokratisasi dan pengakuan akan hak-hak asasi manusia akan melahirkan kuatnya tuntutan terhadap manajemen peningkatan pelayanan publik yang berkualitas. Faktor yang menyebabkan kurang berhasilnya upaya pengembangan sumberdaya manusia berbasis kompetensi ini adalah karena rendahnya budaya belajar dan praktik pengembangan yang tidak mengaitkan antara aktivitas perencanaan hasil, pelatihan, penilaian, dan pengembangan kompetensi berorientasi pekerjaan.

Pada kenyataan bahwa gelagat birokrasi pemerintahan saat ini masih belum merespons dengan menunjukkan kinerja yang sepadan dengan adanya tuntutan tersebut. Kinerja pelayanan yang diberikan oleh birokrasi pemerintahan saat ini menunjukkan adanya, antara lain; aparat birokrasi lebih menampilkan diri sebagi majikan; aparat pelayanan lebih berorientasi pada status quo dari pada peningkatan pelayanan; aparat pelayanan lebih mementingkan prosedur dari pada substansi; aparat pelayanan lebih mementingkan diri sendiri dari pada masyarakat yang harus dilayani.Kajian menganalisis bagaimana aspek akuntabilitas pelayanan publik berasumsi bahwa jika pelayanan publik hanya persoalan managerial semata (perspektif new public management) atau bersifat apolitik maka hasil pelayanan publik belum tentu sesuai dengan keinginan masyarakat. Akan tetapi jika, pelayanan publik merupakan hasil proses politik yang demokratis (perspektif good governance) maka hasil pelayanan publik sesuai dengan keinginan masyarakat. Salah satu masalah pelayanan publik yang menjadi fokus dalam penelitian ini adalah menyangkut masalah akuntabilitas birokrasi dalam pelayanan perizinan mendirikan bangunan di Kota Makassar. Pelayanan ini merupakan salah satu penopang dan pendukung dalam penyelenggaraan Otonomi Daerah, dalam hal ini ada pemasukan keuangan daerah dari sektor perizinan mendirikan bangunan. Artikel ini menganalisis bagaimana akuntabilitas pelayanan perizinan mendirikan bangunan di kota Makassar.

Akuntabilitas dalam pelayanan publik memunyai hubungan dengan kualitas pelayanan publik. Dalam artikel ini, akuntabilitas akan dihubungkan dengan kualitas pelayanan publik ditinjau dari dimensi keterbukaan, kemudahan dalam pemberian pelayanan, ketersediaan sarana, empati/ daya tanggap, rasa aman Dan nyaman.

Lokasi penelitian ini dilakukan di Badan Perizinan Terpadu dan Penanaman Modal Kota Makassar dengan fokus pada Unit Pelayanan Pelayanan Izin Mendirikan Bangunan (IMB) dengan dasar pertimbangan bahwa kontribusi retribusi ini merupakan sumber tertinggi pendapatan asli daerah Kota Makassar. Desain penelitian menggunakan pendekatan kualitatif untuk mendeskripsikan aspekaspek akuntabilitas dan kualitas pelayanan perizianan mendirikan bangunan secara cermat. Penetapan informan dalam penelitian dilakukan dengan purposive sampling. Teknik pengumpulan data yang dipergunakan adalah observasi (pengamatan), wawancara (indepth interview, dan focus group discussion), dokumentasi yang mendukung dan mempertajam analisis data. Sedangkan teknik analisis data yang dipergunakan dimulai dengan reduksi data, penyajian data, analsis data, dan penarikan kesimpulan (Moleong, Lexy J. 2000).

\section{Akuntabilitas dalam Birokrasi Pemerintahan}

Akuntabilitas birokrasi juga diartikan sebagai pertanggungjawaban pemerintah yang lebih ditekankan pada respons pemerintah atas protes/keluhan masyarakat mengenai penyimpangan yang direncanakan 
atau dilaksanakan. Wijaya. A.F (2007: 9) mendefenisikan akuntabilitas sebagai sebuah norma dalam hubungan antara pengambil keputusan dan stakeholders dan para pengambil keputusan bertanggung jawab terhadap konsekuensi yang timbul dari keputusan mereka dalam semua sektor dan tingkatan. Didalam akuntabilitas terdapat komponen penting: (1) pihak yang bertanggung jawab melaksanakan akuntabilitas; (2) pihak-pihak yang mempunyai kewenangan dan hak menanggung gugatan pihak-pihak yang bertanggung jawab; (3) ukuran-ukuran yang dijadikan patokan penilaian akuntabilitas, dan (4) norma atau nilai yang menjadi moral spirit dari sistem akuntabilitas. Sejalan dengan pandangan Dwiyanto (2006: 22) akuntabilitas dalam penyelenggaraan pelayanan publik adalah suatu ukuran yang menunjukkan seberapa besar tingkat kesesuaian penyelenggaraan pelayanan dengan ukuran nilai-nilai atau norma eksternal yang ada di masyarakat atau yang dimiliki oleh para stakeholders. Menurut Jabbra dan Dwivedi (1989: 77), akuntabilitas harus dapat diimplementasikan sebagai suatu kebijakan yang strategis. Oleh karena itu, untuk menjamin adanya kepatuhan aparat pemerintah dalam menjalankan tugasnya perlu memahami dan menerapkan lima akuntabilitas; yaitu moral, administratif, profesional, legal dan politik.

Selanjutnya, Darwin, M. (1996: 98), menekankan bahwa birokrasi publik dapat disebut memiliki akuntabilitas publik apabila mereka dinilai secara objektif oleh masyarakat. Dengan demikian, akuntabilitas publik merupakan kewajiban birokrasi publik untuk menyampaikan pertanggungjawaban dengan menjelaskan dan menjawab atas tindakan yang mereka lakukan (atau mereka tidak lakukan) kepada publik atau masyarakat sebagai pemberi amanah.

Media akuntabilitas yang baik dapat berbentuk laporan yang dapat mengekpresikan pencapaian tujuan melalui pengelolaan sumber daya suatu organisasi, karena pencapaian tujuan merupakan salah satu ukuran kinerja individu maupun organisasi. Tujuan tersebut dapat dilihat dalam rencana strategik organisasi, rencana kinerja, dan program kerja tahunan, dengan tetap berpegang pada Rencana Jangka Panjang dan Menengah dan Rencana Kerja Pemerintah.

\section{Jenis-Jenis Akuntabilitas Publik}

Ferlie et al (1996: 202) membedakan beberapa model akuntabilitas, yaitu: akuntabilitas ke atas (accountability up-wards), akuntabilitas kepada staff (accountability to staff), akuntabilitas ke bawah (accountability downwards), akuntabilitas yang berbasis pasar (market-based forms of accountability), dan akuntabilitas kepada diri sendiri (self accountability). Bentuk dimensi pertanggungjawaban publik oleh pemerintah yang dikemukakan oleh Ellwood (dalam Halim 2007:43), yaitu: akuntabilitas hukum dan peraturan (accountability for probity and legality), akuntabilitas proses (process accountability), akuntabilitas program (program accountability), dan akuntabilitas kebijakan (policy accountability).

Mc. Kinney et al $(1998 ; 45)$ membagi beberapa jenis akuntabilitas, yaitu, (1) akuntabilitas fiskal (fiscal accountability); (2) akuntabilitas legal (legal accountability); (3) akuntabilitas program (program accountability); (4) akuntabilitas proses (process accountability); (5) akuntabilitas hasil (outcome accountability); dan (6) akuntabilitas berkelanjutan (sustainability accountability).

Selanjutnya, Romzek dan Dubnick (1987: 101) sebagaimana Gormley dan Balla (2004: 11), dan Romzek dan Dubnick (2000: 39) menggunakan konsep akuntabilitas herarki, serta Prasojo, dkk (2009: 55) melihat akuntabilitas dalam sektor publik pada empat aspek berdasarkan sumber kontrol, yaitu akuntabilitas birokratik/ administratif, akuntabilitas legal, akuntabilitas professional, dan akuntabilitas politik.

Identifikasi tipe akuntabilitas yang dilakukan dalam tulisan ini bermaksud untuk menggambarkan jumlah tipe akuntabilitas yang telah dikembangkan atau digunakan untuk mengkaji akuntabilitas, tetapi tidak bermaksud menggukan semuanya untuk penelitian ini. Akuntabilitas birokrasi, konsep ini digunakan oleh Erkkila (2007: 88), sedangkan Jabbra dan Dwivedi (1989: 77) menggunakan konsep akuntabilitas administratif/organisasional.

Oleh karena itu, dalam mengkaji akuntabilitas penulis mengemukakan penjelasan singkat berkenaan dengan aspek legalitas, aspek profesionalitas, aspek kewenangan dan aspek pengawasan (kontrol) serta aspek moralitas, adalah: (1) aspek legalitas, akuntabilitas birokrasi dari aspek legalitas merupakan akuntabilitas hukum dan peraturan yang menekankan jaminan adanya kepatuhan terhadap hukum 
dan peraturan lain yang disyaratkan dalam pelaksanaan pelayanan perizinan mendirikan bangunan dengan menggunakan sarana seperti konstitusi, peraturan-peraturan teknis, dan delegasi kewenangan formal; (2) aspek profesionalitas, bentuk akuntabilitas birokrasi pemerintah daerah, atas kemampuan sumber daya manusia yang dimiliki untuk melaksanakan layanan perizinan mendirikan bangunan kepada masyarakat; (3) aspek kewenangan, adanya hubungan yang hierarki yang tegas di antara pusat-pusat pertanggungjawaban dengan unit-unit di bawahnya. Hubungan hierarki biasanya telah ditetapkan dengan jelas, baik dalam bentuk aturan-aturan organisasi yang telah ditetapkan secara formal ataupun dalam bentuk jaringan hubungan informal; dan (4) aspek pengawasan, upaya-upaya dalam melakukan control baik pada pelayanan yang bersifat administratif maupun pelayanan yang bersifat teknis dalam memberikan pelayananperizinan mendirikan bangunan; (5) moralitas berkaitan dengan integritas pegawai dalam pelayanan perizinan (jujur, ramah, sopan, penolong, dan sikap positif lainnya).

\section{Dimensi Akuntabilitas dalam Pe- layanan Publik}

Pola akuntabilitas memiliki dua dimensi sebagaimana yang dikemukakan oleh Moncieffe dalam Suryono. (2001:98), yakni (1) ex-post facto accountability, dan (2) ex-ante accountability. Ex-post facto yang pada intinya mengharuskan pejabat dan lembaga publik untuk bertanggung jawab atas kewenangan yang ada pada mereka (answering for the use of authority) melalui norma hukum, monitoring sistem, mekanisme penilaian (appraisal mechanism) melalui lembaga publik lain yang independen (seperti institusi auditor dan kejaksaan) yang diberikan hak untuk memeriksakan setiap lembaga publik terhadap rasionalisme kinerja yang dilakukan oleh birokrasi. Sedangkan prinsip ex-ante (positive) accountability pada intinya mengharuskan pejabat publik untuk selalu merepresentasikan keinginan rakyat dalam setiap pelaksanaan kebijakan yang mereka lakukan.

Pejabat publik harus selalu mengonsultasikan secara terus-menerus setiap tindakan pada publik, memberikan alternatif pilihan atau solusi, memberikan informasi atau penjelasan yang lengkap, dan juga menyediakan mekanisme bagi publik untuk memberikan masukan atau mengecek kualitas kebijakan para pejabat serta merevisinya bila dipandang perlu.

Selanjutnya, beberapa konsepsi tentang media yang dapat ditempuh dalam mewujudkan akuntabilitas dalam pelayanan publik, yaitu transparansi (keterbukaan), liability (kewajiban), controllability (keterkendalian), responsibility (tanggungjawab), dan responsiveness (ketanggapan). Pemahaman atas lima prinsip akuntabilitas merupakan tahap penting sebelum melakukan evaluasi atas akuntabilitas organisasi atau individu. Untuk menilai apakah suatu organisasi akuntabel sangat bergantung pada prinsip akuntabilitas memiliki makna dan fokus pengukuran yang berbeda.

\section{Dimensi Kualitas Pelayanan Publik}

Denhardt and Denhardt (2003:22-24) menjelaskan pendekatan New Public Services menuju pada perubahan orientasi warga negara (citizen) pada bagaimana institusi publik dibangun berdasarkan integritas dan responsivitas. Bagaimana peran pemerintah dalam melayani dan memberdayakan serta nilai-nilai demokrasi.Pelayanan yang demokratis menuntut terwujudnya pelayanan berkualitas sebagai salah satu bentuk tata kelola pemerintahan yang baik (good governance).

Hal seperti inilah yang menyebabkan upaya penegakan local good governance, yang dicirikan dengan penyelenggaraan pemerintahan yang akuntabel, transparan, dan partisipatif. Pelayanan publik mengandung makna aktivitas yang memberikan kemudahan kepada masyarakat dalam rangka memenuhi kepentingan sesuai dengan kebutuhan penerima pelayanan, baik barang atau jasa berdasarkan peraturan yang telah ditetapkan dengan harapan dapat memuaskan(satisfaction) penerima pelayanan. Carlson dan Schwarz (1995:29), dalam Denhardt (2003: 61) menjelaskan,

bahwa untuk mengukur kualitas layanan sektor publik dapat dilihat dari kemudahan/kenyaman, keamanan, keandalan/reliabilitas, perhatian kepada orang/personal, pendekatan pemecahan masalah, keadilan/ kejujuran, tanggung jawab fiskal, pengaruh warga Negaraterhadap kualitas pelayanan yang mereka terima dari pemerintah daerah.

Sinambela (2006: 6) secara teoretis tujuan pelayanan publik pada dasarnya adalah memuaskan masyarakat. Untuk mencapai kepuasan itu dituntut kualitas pelayanan prima yang tercermin dari transparansi, 
akuntabilitas, kondisional, yakni pelayanan yang sesuai kondisi dan kemampuan pemberi dan penerima pelayanan dengan tetap berpegang pada prinsif efisien dan efektivitas, partisipatif, kesamaan hak, dan keseimbangan hak dan kewajiban.

Menurut Zeithaml, et al $(1990 ; 65)$ mengemukakan bahwa ada 10 dimensi yang harus diperhatikan dalam melihat tolok ukur kualitas pelayanan publik, sebagai berikut: tangibles, terdiri atas fasilitas fisik, peralatan, personil dan komunikasi; reliable, kemampuan unit pelayanan dalam menciptakan pelayanan yang dijanjikan dengan tepat; responsiveness, kemampuan untuk membantu konsumen bertanggung jawab terhadap kualitas pelayanan yang diberikan; competence, tuntutan yang dimilikinya, pengetahuan dan keterampilan yang baik oleh aparatur dalam memberikan pelayanan; courtesy, sikap atau perilaku ramah, bersahabat, tanggap terhadap keinginan konsumen serta mau melakukan kontak atau hubungan pribadi; credibility, sikap jujur dalam setiap upaya untuk menarik kepercayaan masyarakat; security, jasa pelayanan yang diberikan harus bebas dari berbagai bahaya dan risiko; acces, kemudahan untuk mengadakan kontak dan pendekatan; communication, kemauan pemberi pelayanan untuk mendengarkan suara, keingintahuan atau aspirasi pelanggan, sekaligus ketersediaan untuk selalu menyampaikan informasi baru kepada masyarakat; dan understanding the custumer, melakukan segala usaha untuk mengetahui kebutuhan pelanggan.

\section{Pelayanan Perizinan Mendirikan Bangunan}

Konsistensi legalitas pelayanan perizinan mendirikan bangunan di Kota Makassar dilihat dari Peraturan Walikota Makassar Nomor 14 Tahun 2005 mengatur Mekanisme Pelayanan Perizinan, Peraturan Walikota Makassar Nomor 8 Tahun 2014 tentang Pelimpahan Wewenang Perizinan kepada Badan Perizinan Terpadu dan Penanaman Modal ( BPTPM) bertujuan untuk meningkatkan kualitas pelayanan. Kemudian, Pemerintah Kota Makassar sebagai daerah otonom diamanatkan untuk meningkatan Pendapatan Asli Daerah (PAD) yang bersumber dari pajak, restribusi, dan nonretribusi sesuai Undang-Undang No. 28 Tahun 2009.

Kemudian ditindaklanjuti dengan terbitnya Peraturan Daerah Kota Makassar Nomor 5 Tahun 2012 tentang Retribusi Perizinan Tertentu. Secara operasional ditindaklanjuti lagi dengan Peraturan Walikota Makassar Nomor 20 Tahun 2014 tentang Tata Cara Pemberian Izin pada Pemerintah Kota Makassar. Jika substansi tata cara perizinanan dilaksanakan dengan konsisten akan memberikan kepuasan kepada masyarakat sebagai bentuk akuntabilitas pelayanan publik. Kepuasan masyarakat harus didahulukan dalam pelayanan sesuai dengan Kep-Menpan Nomor KEP/25/M. PAN/2/2004.

Berdasarkan hasil penelitian ditemukan bahwa legalitas pelayanan perizinan belum maksimal, terkendala dengan kurang sosialisasi

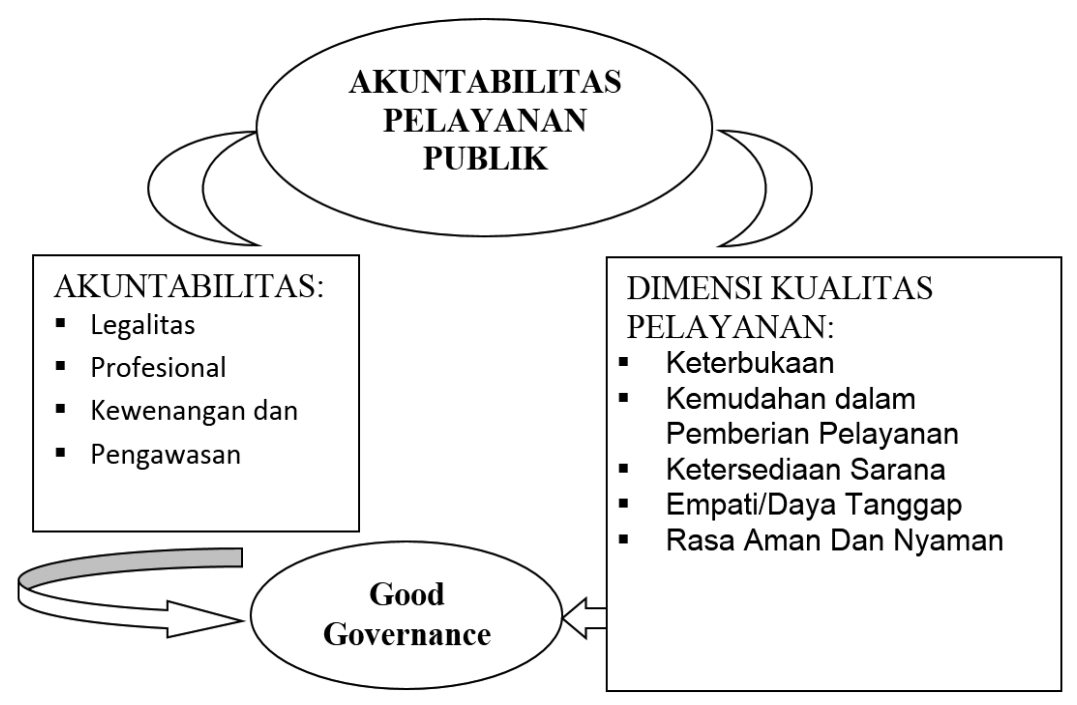

Gambar 1 Kerangka Pemikiran 
peraturan tersebut dan kurang terampilnya aparat pelayanan dalam menggunakan komputer, sehingga mengangganggu proses penyelesaian pekerjaan. Selain itu, Standar operasional prosedur (SOP) belum berjalan secara maksimal sehingga kurang efektif dan efisien dalam menyelesaikan pekerjaan. Di samping itu, penggunaan objek Izin Mendirikan Bangunan (IMB) sangat dinamis sehingga cenderung menyalahi izin pembangunannya, misalnya toko menjadi hotel, toko menjadi tempat hiburan, dan lain-lain. Selain itu, kesadaran masyarakat masih rendah mengurus izin mendirikan bangunan. Hal ini, banyak bangunan liar tanpa IMB, sehingga menganggu tata ruang kota Makassar.

Peraturan dibuat untuk mendorong keterbukaan dalam pelayanan IMB, namun pelayanan transaksional di luar loket pelayanan masih sering terjadi antara masyarakat pengguna dengan aparat pelayan.Kondisi ini memunculkan kecurigaan terjadinya penyuapan, gratifikasi, dan ketidakadilan di antara masyarakat pengguna. Namun, dengan sistem pelayanan satu pintu mendorong peningkatan akuntabilitas dan kualitas pelayanan izin mendirikan bangunan di kota Makassar dibandingkan sistem palayanan administrasi pelayanan secara parsial (dilakukan sendiri oleh Satuan Kerja Perangkat Daerah [SKPD]).

Profesionalisme pelayanan perizinan mendirikan bangunan di kota Makassar merupakan dimensi yang menentukan akuntabilitas institusi terhadap masyarakat. Semakin tinggi tingkat profesionalisme aparatur semakin berkualitas pelayanan public.Dari 45 pegawai yang ada di BPTPM pada umumnya berpendidikan S1 dan S2 $(86,67 \%)$ dengan tingkat golongan III dan IV sebesarnya $77 \%$. Hal ini berarti peningkatan profesionalime aparatur akan mudah dilakukan jika ada regulasi dan biaya pengembangan kapasitas aparatur. Berdasarkan hasil interview beberapa informan menyebutkan, dari sisi pendidikan dan golongan cukup baik mendukung pelaksanaan pekerjaan, namun pegawai secara teknis kurang terampil menggunakan komputer, kurang memahami seluk-beluk terkait perizinan mendirikan bangunan, sehingga sulit memberikan informasi yang akurat kepada pengguna layanan, kurang terampil dalam perhitungan IMB. Untuk itu, mengembangan kapasitas dan profesionalisme aparatur harus dilakukan secara terintegrasi antara pengembangan pengetahuan dengan keterampilan teknis terkait aturan, prosedur, komunikasi, dan empati terhadap pengguna layanan.

Konsistensi kewenangan pelayanan perizinan mendirikan bangunan di kota Makassar didasarkan pada Peraturan Walikota Makassar Nomor 8 Tahun 2014 tentang pelimpahan wewenang perizinan dan non perizinan kepada Badan Perizinanan Terpadu dan Penanaman Modal Kota Makassar. Namun secara operasional pelayanan IMB tetap melakukan koordinasi dengan Dinas Tata Ruang dan Bangunan. Karena setiap IMB yang akan diterbitkan terlebih dahulu harus mendapatkan rekomendasi dari Dinas Tata Ruang dan Bangunan. Kewenangan yang diberikan kepada BPTPM adalah mengeluarkan Izin Mendirikan Bangunan (IMB).

Beberapa informan menyebutkan bahwa meskipun kewenangan penerbitan IMB dilakukan BPTPM kota Makassar, tetapi secara teknis terlebih dahulu dilakukan kajian di lapangan untuk menilai obyek IMB yang dilakukan oleh Bidang Kajian Teknis Dinas Tata Ruang dan Bangunan, selanjutnya dikeluarkan rekomendasi terkait obyek tersebut untuk disampaikan kepada pejabat BPTPM yang berwenang. Jika dilihat dari asas efisiensi dan efektivitas pengurusan IMB dapat dikategorikan belum maksimal. Idealnya bagi pelayanan satu pintu, pejabat teknis dari Dinas Tata Ruang dan Bangunan terkait pengurusan IMB berada dalam satu kantor (ruangan) agar masyarakat pengguna memperoleh kemudahan pelayanan.

Pengawasan pelayanan perizinan mendirikan bangunan di kota Makassar bertujuan untuk memastikan bahwa aktivitas atau pekerjaan yang dilakukan oleh bawahan terlaksana dengan rencana semula. Dasar hukum sistem pengawasan di BPTPM kota Makassar, yaitu: PP No. 53 Tahun 2010 tentang Disiplin Pegawai Negeri Sipil dan Kep-Menpan Nomor KEP/46/M.PAN/4/2004 tentang Petunjuk Pengawasan Melekat dalam Penyelenggaraan Pemerintahan.

Berdasarkan hasil wawancara dengan beberapa informan, sistem pengawasan yang yang diterapkan di BPTPM dalam memberikan pelayanan IMB, yaitu pengawasan langsung dari kepada Bidang Pelayanan Perizinan.Selain itu pengawasan langsung juga dilakukan oleh pejabat teknis dari Dinas Tata Ruang dan Bangunan, kecamatan, dan kelurahan untuk menilai objek IMB yang disulkan.Sistem pengawasan seperti ini dianggap lebih efektif karena terjadi komunikasi secara langsung antara pemerintah dengan masyarakat, 
sehingga mendorong semua jenis bangunan memiliki izin mendirikan bangunan. Selain itu, pengawasan yang efektif dalam pengurusan dan kepemilikan IMB dapat meningkatkan Pendapatan Asli Daerah (PAD) di sektor retribusi perizinanan. Tantangan yang dihadapi oleh pejabat pada tingkat kelurahan, kecamatan, Dinas Tata Ruang dan Bangunan adalah mengajak masyarakat memiliki IMB bagi bangunan liar yang cukup banyak di kota Makassar.

Dimensi keterbukaan dalam pelayanan merupakan salah satu indikator dalam mewujudkan kinerja pemerintahan dan tata kelola pemerintahan yang baik (good governance). Keterbukaan yang diharapkan oleh masyarakat pengguna dalam pelayanan IMB antara lain: kepastian biaya, waktu, dan persyaratan administratif. Namun, menurut informan, prinsip keterbukaan belum maksimal, terutama kepastian biaya dan waktu penyelesaian IMB.Sedangkan Prosedur dan kemudahan pelayanan merupakan dambaan masyarakat pengguna layanan agar efektivitas dan efisiensi pelayanan dapat terwujud. Menurut beberapa informan, meskipun pelayanan sudah menggunakan sistem satu pintu, namun mereka merasakan pelayanan yang cukup berbelit-belit sehingga pengurusan IMB cukup lama, antara 2 sampai 5 bulan.Kondisi ini bertentangan dengan misi pernyataan Kepala BPTPM bahwa dengan pelayanan satu pintu maka pengurusan IMB paling lama 12 hari kerja.

Pelayanan satu pintu membutuhkan fasilitas ruang tunggu yang memadai dan kondusif agar terciptanya kenyamanan dan keamanan mengikuti prosedur pengurusan IMB.Namun, menurut beberapa informan, ketersediaan fasilitas kursi tidak cukup memenuhi kebutuhan pengguna layanan. Ruangan tunggu semestinya diperluas dengan alat pendingin (AC) dan TV, bahan bacaan untuk pengguna layanan.Sedangkan yang berkaitan dengan rentang waktu penyelesaian pengurusan IMB, masyarakat pengguna sangat mendambakan penyelesaian IMB tepat dan cepat. Namun menurut beberapa informan bahwa mereka bolak-balik mengurus dan menanyakan tingkat penyelesaian IMB karena tidak ada kepastian waktu. Kondisi seperti ini cenderung terjadi kekesalan (menggerutu, emosi) karena tidak ada kepastian waktu.

Kualitas pelayanan IMB dapat berjalan harmonis jika ada rasa empati dan daya tanggap pegawai yang melayani masyarakat pengguna sepenuh hati, mengedepankan kepuasan pelanggan. Menurut beberapa informan, empati dan daya tanggap pegawai terhadap pengguna layanan cukup baik. Pada umumnya pegawai memberikan penjelasan atas pertanyaan-pertanyaan yang diajukan masyarakat pengguna.Namun masih ditemukan pegawai kurang tanggap karena pegawai tersebut merasa terganggu bekerja jika ada masyatakat pengguna meminta penjelasan terkait pengurusan IMB.

Efektivitas dan efisiensi pelaksanaan pekerjaan sangat tergantung pada kehandalan aparatur baik dari segi kemampuan maupun keterampilan dalam melaksanakan tugas pokok dan fungsinya. Menurut beberapa informan, petugas pelayanan cukup mampu dan terampil menggunakan teknologi komputer, hanya saja mereka lambat mengetik sehingga proses penyelesaian suatu pekerjaan cukup lama. Sedangkan kemampuan sosialnya (bijak, sopan, ramah) kepada pengguna layanan cukup baik.

Setiap pengguna layanan membutuhkan perasaan aman dan nyaman dalam pengurusan IMB di Kantor BPTPM kota Makassar. Jika kebutuhan ini terpenuhi masyarakat pengguna akan semakin respek kepada pegawai dan organisasi sehingga mereka taat aturan.

Menurut beberapa informan, selama mengurus IMB mereka merasa cukup aman dan nyaman, namun masih ada beberapa sumber keresahan yang kadang-kadang muncul, misalnya dijanji IMB sudah selesai besok harinya, pada saat kami datang ternyata belum ditandatangani oleh pejabat berwenang karena sibuk (rapat), acara di luar kantor. Rasa aman dan nyaman bagi masyarakat pengguna cukup baik karena sudah disiapkan loket dan ruang tunggu yang cukup kondusif, namun dirasa sumpek karena ruangan terlalu sempit.

\section{Simpulan dan Saran}

Akuntabilitas pelayanan perizinan mendirikan bangunan di kota Makassar akan mendorong peningkatan kinerja pelayanan, sehingga penerimaan PAD dari retribusi IMB dapat meningkat dari tahun ke tahun. Hasil penelitian menunjukkan bahwa rendahnya kesadaran masyarakat mengurus IMB disebabkan oleh kurang sosialisasi peraturanperaturan yang terkait IMB.Kurang efektif dan efisiensi pengurusan IMB disebabkan oleh kurang terampilnya petugas pelayanan menggunakan komputer pengolah data. Kondisi ini berdampak pada pengurusan IMB 
tidak dapat selesai tepat waktunya.

Meskipun pelayanan IMB sudah dilakukan dengan sistem pelayanan satu pintu dengan harapan pelayanan prima dapat terwujud, namun pada kenyataannya kendala oleh penerapan standar operasional prosedur yang belum maksimal, kewenangan belum fokus pada BPTPM karena sebelum IMB diterbitkan terdahulu harus ada rekomendasi dari hasil kajian teknis Dinas Tata Ruang dan Bangunan. Kualitas pelayanan sudah lebih baik dibandingkan sebelum diterapkan pelayanan satu pintu, namun masih perlu ditingkatkan dari aspek profesionalisme aparatur, sarana dan prasarana, serta penggunan eletronik pemerintahan secara online dalam pelayanan perizinan mendirikan bangunan.

Namun disaranka, sudah saatnya dilakukan transformasi perizinan dalam bentuk electronik administration (e-Adm) untuk memudahkan mendaptkan informasi, mudah interaksi secara terbuka antara petugas pelayanan dengan masyarakat pengguna, secara online juga akan menghindari pungutan liar, suap dan gratifikasi.

\section{Daftar Pustaka}

Carlson, Margaret S.and Roger Schwarz, (1995). "What Do Citizens Really Want?"Popular Goverment (Spring): 26-33.

Darwin, M. (1996). Demokrasi Indonesia Kontemporer. Jakarta. Raja Grafindo Persada.

Denhardt, J.V., and Denhardt, R.B. (2003). The New Public Service: Serving, Not Steering. New York:M.E. Sharpe.

Dwiyanto, Agus. (2006). Reformasi Birokrasi Publik di Indonesia.Pusat Studi Kependudukan dan Kebijakan. Univeritas Gadjah Mada. Yogjakarta.

Effendi, Nur.(2015). Pengembangan Sumberdaya Manusia Berbasis Kompetensi di Kantor Pemerintah Kota Bandar Lampung. Mimbar Jurnal Sosial dan Pembangunan. Volume 31 No. 1 Tahun 2015. Unisba. Bandung.

Erkkila, Tero. (2007). Governance and Accountability: A Shift in Conceptualisation, PAQ Spring.

Ferlie, E. et al. (1996). The New Public Managementin Action. Washington, Oxford University Press.

Gormley Jr., William T dan Balla, Steven J. (2004). "Bureaucracy and Democracy: Accountability and Performance," CQ Press, Washington, D.C.20037.

Halim, Abdul. (2007). Akuntansi dan
Pengendalian Pengelolaan Keuangan Daerah. Yogjakarta. UPP STIM YKPN.

Jabbra, J.G.and Dwivedi O.P (1989). Public Service Accountability; A Comparative Perspective. Kumarian Press, Inc.

Kumorotomo, Wahyudi. (1999). Etika Administrasi Negara. Raja Grafindo Persada. Jakarta.

Mc. Kinney, Joreme B. Dan Lawrence C. Howard, (1998). Public Administration: Balancing Power and Accountability, Second Edition, Praregar Westport Conectitut: London

Moleong, Lexy J. (2000). Metodologi Penelitian Kualitatif. Cetakan Ketiga, PT Remaja Rosdakarya. Bandung.

Prasojo, Eko. (2009). Reformasi Kedua: Melanjutkan Estafet Reformasi. Salemba Humanika, Jakarta.

Romzek, B. (2000). Dynamics of Public Sector Accountability in Era of Reform. International Review of Administrative Sciences, 66.

Romzek, B.S. dan Melvin J. Dubnick. (1987). Accountability in the Public Sector Lesson from the Challenger Tragedy. Public Administration Review 47 (3).

Suryono, Agus. (2001). "Budaya Birokrasi Pelayanan Publik." Jurnal Ilmiah Administrasi Negara, Vol. 1 No. 2, Maret 2001: 49-58. FIA Universitas Brawijaya. Malang.

Thoha, M. (1998). Debirokratisasi Peningkatan Mutu Pelayanan Masyarakat dalam Pembangunan Administrasi di Indonesia. Jakarta. LP3ES.

Wijaya, A.F. (2007). "Akuntabilitas Aparatur Pemda dalam Era Good Governance dan Otonomi Daerah." Jurnal Ilmiah Administrasi Publik, Vol VIII No.2. MaretAgustus 2007: 537-552. FIA Universitas Brawijaya. Malang.

Zeithaml, V.A., A. Parasuraman and L.L. Berry. (1990). Delivering Quality Services: Balancing Customer Perceptions and Expectation. New York: The Free Press.

Peraturan dan Perundang-Undangan:

Undang-Undang No. 32 Tahun 2004 Tentang Pemerintahan Daerah.

Undang-Undang N0. 28 Tahun 2009 Tentang Pajak Daerah dan Retribusi Daerah.

Inpres No. 7 Tahun 1999 Tentang AKIP (Akuntabilitas Kinerja Instansi Pemerintah)

Keputusan Kepala LAN No.239/IX/6/Y/2003 Tentang Pedoman Penyusunan Pelaporan AKIP (Akuntabilitas Kinerja Instansi Pemerintah)

Peraturan Walikota Makassar Nomor 14 Tahun 2005 tentang Mekanisme Pelayanan Perizinan.

Peraturan Walikota Makassar Nomor 8 Tahun 2014 tentang pelimpahan wewenang perizinan kepada Badan Perizinan Terpadu dan Penanaman Modal (BPTPM). 